\title{
Mushrooms as natural antiviral sources and supplements foods against coronavirus (COVID-19)
}

\begin{abstract}
Coronavirus (COVID-19) is a disease that has caused a lot of casualties worldwide. After the pandemic announcement, it infected quite a lot of people and had serious mortality in many countries. The prevalence of the disease, especially in people with weak immune systems and individuals with chronic diseases, has brought to the fore different protection methods and supplements that strengthen the immune system. In this context, it is important to evaluate mushrooms, which are important supplements. Mushrooms are natural products with many biological activities. In this research we have done, the antiviral activity of fungi has been emphasized. In addition, it is recommended that mushrooms should be evaluated as both supplements and natural antiviral drugs against COVID-19.
\end{abstract}

Keywords: coronavirus, mushrooms, antiviral sources, pneumonia, COVID-19
Volume 9 Issue 2 - 2021

\author{
Mustafa SEVINDIK \\ Department of Food Processing, Osmaniye Korkut Ata \\ University, Turkey
}

\begin{abstract}
Correspondence: Mustafa SEVINDİK, Department of Food Processing, Bahçe Vocational School, Osmaniye Korkut Ata University, Osmaniye, Turkey, Tel +90 5327484228, Email sevindik27@gmail.com
\end{abstract}

Received: May 09, 2021 | Published: May 19, 2021

\section{Introduction}

The new type of coronavirus, the infectious pneumonia epidemic that started in the central China's Wuhan province in December 2019, was named Coronavirus (COVID-19) by the WHO, SARS-CoV-2 by the International Virus Taxonomy Committee. After the World Health Organization announced the global pandemic as of March 28,2020 , the new type of coronavirus, which was transmitted to $162,773.940$ people in the world as of May 17, 2021, died 3,375.573 people worldwide (Figure 1). ${ }^{1}$ Approximately 2-14 days after the virus infection, high fever, chills, dry cough, dyspnea, weakness, joint, muscle, head and throat pains, loss of taste and smell, nasal congestion and runny, nausea and vomiting, diarrhea are observed. There have been many similar epidemics in the historical process. Diseases such as Black Plague, Cholera, Flu, Typhoid, Swine Flu have been declared as pandemics.,3 COVID-19 attacks the lower airways, causing viral pneumonia. In addition, it may affect the gastrointestinal system, heart, kidney, liver, and central nervous system, leading to multi-organ failure. ${ }^{4,5}$ Many different drugs are used in the treatment of COVID-19. In addition, supplementary foods that support the immune system are recommended. In this study, mushrooms, which are natural products that support the immune system, are focused on.

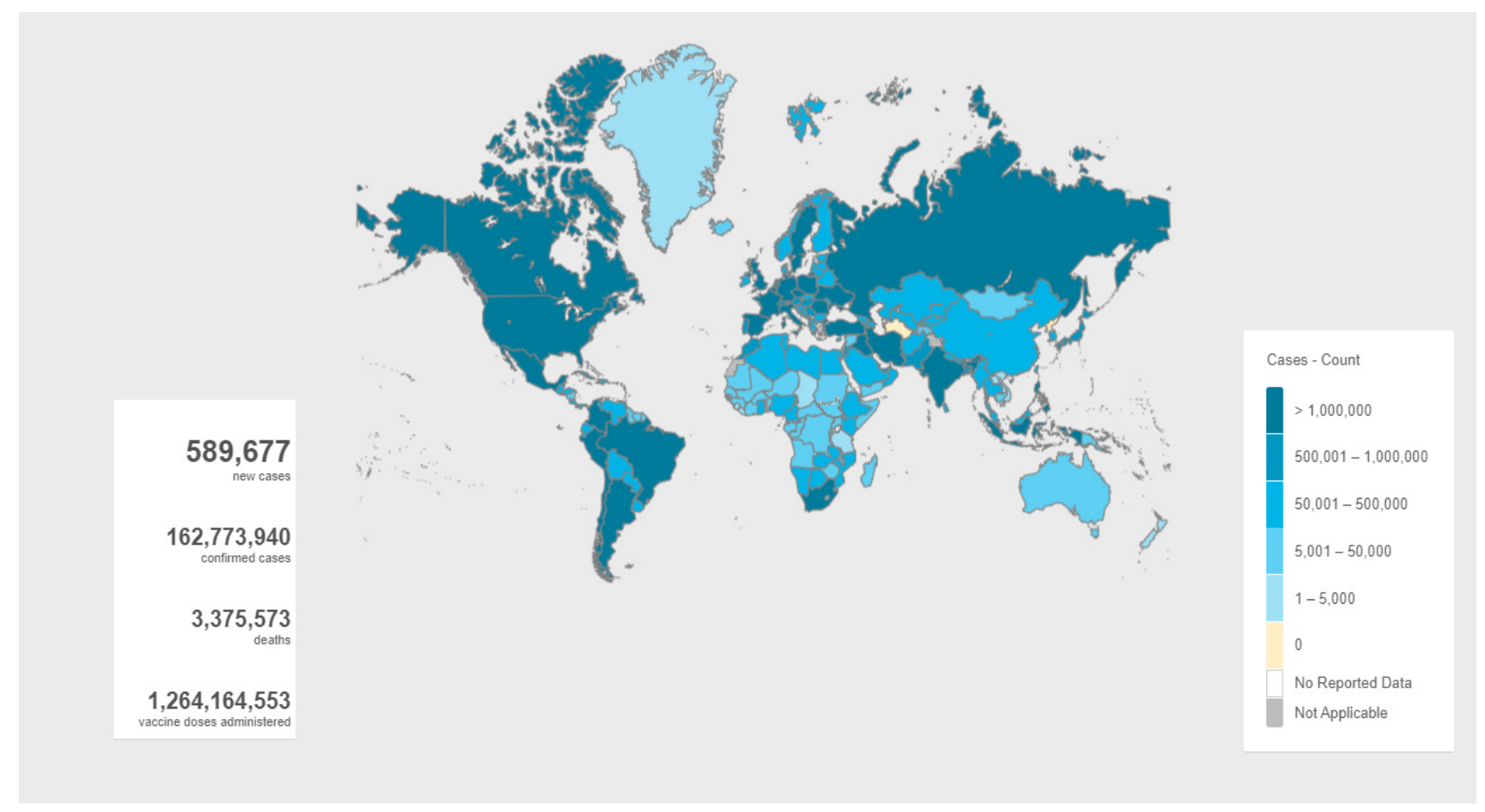

Figure I Countries, territories or areas with reported confirmed cases of COVID-19, 17 May 202I. 
Mushrooms have been used by people for different purposes since ancient times. ${ }^{6,7}$ They have been used in different communities as food, medicine, religious rituals, and poison. We can group mushrooms as poisonous, edible and inedible. ${ }^{8,9}$ In this context, when poisonous mushrooms are consumed, they can show lethal effects as well as gastrointestinal disorders. ${ }^{10,11}$ Edible mushrooms, on the other hand, are food products with very good nutritional properties. ${ }^{12,13}$ It is especially low in fat content, rich in protein, chitin, vitamins and minerals, and is an essential element of low calorie diets. ${ }^{14,15}$ Inedible mushrooms are hard and tasteless mushrooms that do not have toxic or nutritious properties. Inedible mushrooms are distinguished by their medicinal properties. ${ }^{16,17}$ In recent years, the medicinal properties of mushrooms as well as their nutritional properties have been reported by many researchers. In this context, the interest of researchers in the research of the pharmaceutical potential of mushrooms is increasing. ${ }^{18-21}$ Many studies have shown the existence of biologically active molecules produced within the body of fungi. ${ }^{22}$ Fruit bodies and cultured myceliums have been reported to contain polysaccharides, proteins, oils, minerals, glycosides, alkaloids, essential oils, terpenoids, tocopherols, phenolics, flavonoids, carotenoids, folates, lectins, enzymes, ascorbic and organic acids. ${ }^{23-26}$ Especially polysaccharide groups and $\beta$-glucans are versatile metabolites with a wide spectrum of biological activity. ${ }^{26-28}$ In many studies conducted in this context, it has been reported that mushrooms have different biological effects such as antioxidant, antiproliferative, antiallergic, immunomodulatory, antiviral, antibacterial, antiparasitic, antifungal, anticholesterolemic, hepatoprotective, DNA preservative, anticancer, and anti-inflammatory. ${ }^{29-41}$ In addition to these biological effects, antiviral effects of fungi against COVID-19 can be used. Many studies have shown that different types of fungi have anti-viral effects (Table 1). ${ }^{42-55}$ As stated in the literature, it is seen that many different mushroom extracts or compounds isolated from fungi have antiviral effects (Table 1). It is thought to be a type of mushroom that has not been researched but has medicinal properties. In this context, mushrooms, which are indispensable elements of natural ecosystems, can be used to combat COVID-19 and many different viral diseases.

Table I Antiviral activities of some mushrooms

\begin{tabular}{lcc}
\hline Mushroom name & Virus & Compounds \\
\hline Rhodotus palmatus (Bull.) Maire & Hepatitis C & Meroterpenoid and \\
& 42 & Sesquiterpenoids
\end{tabular}

Boletus edulis Bull., Fomes fomentarius (L.) Fr., Laetiporus sulphureus (Bull.) Murrill, Lentinus edodes (Current name: Lentinula edodes (Berk.) Pegler), Morchella conica (Current name: Morchella esculenta (L.) Pers.), Morchella esculenta, Phellinus igniarius (L.) Quél., Phellinus pini (Current name: Porodaedalea pini (Brot.) Murrill), Pleurotus ostreatus (Jacq.) P. Kumm., Porodaedalea pini (Brot.) Murrill, Pyrofomes demidoffii (Lév.) Kotl. \& Pouzar, Rozites caperata (Current name: Cortinarius caperatus (Pers.) Fr.), Terfezia boudieri Chatin, Tricholoma anatolicum H.H. Doğan \& Intini

Daedaleopsis confragosa (Bolton) J. Schröt., Datronia mollis (Current name: Cerioporus mollis (Sommerf.) Zmitr. \& Kovalenko), Ischnoderma benzoinum (Wahlenb.) P. Karst., Laricifomes officinalis (Current name: Fomitopsis officinalis (Vill.) Bondartsev \& Singer), Lenzites betulina (L.) Fr., Trametes gibbosa (Pers.) Fr., Trametes versicolor (L.) Lloyd

Ganoderma lucidum (Curtis) P. Karst., Hericium erinaceus (Bull.) Pers., Lignosus rhinocerotis (Cooke) Ryvarden, Pleurotus giganteus (Berk.) Karun. \& K.D. Hyde, Schizophyllum commune Fr.,

Agaricus brasiliensis Fr., Cordyceps sinensis (Current name: Ophiocordyceps sinensis (Berk.) G.H. Sung, J.M. Sung, HywelJones \& Spatafora), Ganoderma lucidum(Curtis) P. Karst., Grifola frondosa (Dicks.) Gray, Lentinus edodes (Current name: Lentinula edodes (Berk.) Pegler), Trametes versicolor (L.) Lloyd,

Cantharellus isabellinus Heinem., Cantharellus platyphyllus (Current name: Afrocantharellus platyphyllus (Heinem.) Tibuhwa), Pleurotus citrinopileatus Singer, Pleurotus djamor (Rumph. ex Fr.) Boedijn, Pleurotus sajor-caju (Current name: Lentinus sajor-caju (Fr.) Fr.)

Hypoxylon fuscum (Pers.) Fr.

Auriporia aurea (Peck) Ryvarden, Flammulina velutipes (Curtis) Singer, Fomes fomentarius (L.) Fr., Ganoderma lucidum(Curtis) P. Karst., Lentinus edodes (Current name: Lentinula edodes (Berk.) Pegler), Lyophyllum shimeji (Kawam.) Hongo, Pleurotus eryngii (DC.) Quél., Pleurotus ostreatus (Jacq.) P. Kumm., Schizophyllum commune Fr., Trametes versicolor (L.) Lloyd
Herpes

simplex virus types I (HSV-I)

Type $\mathrm{A}$ influenza virus of birds ( $\mathrm{H} 5 \mathrm{NI})$ and humans $\mathrm{A}(\mathrm{H} 3 \mathrm{~N} 2)$

\section{Dengue Virus 2}

RC-I83,

Methanol and

aqueous extracts, polysaccharide

Aqueous extracts

Hot aqueous, ethanol, hexane, ethyl acetate and aqueous extracts

Infectious bursal disease virüs, Poxviridae

Methanol extract

Echoviruses (E7, EI3, and EI9)

Methanol extract

HINI (influenza A virus subtype), HSV2 (Herpes

Mycelial extracts 
Table Continued.

\begin{tabular}{|c|c|c|c|}
\hline Mushroom name & Virus & Compounds & Literature \\
\hline Agaricus brasiliensis Fr. & Poliovirus type I & Polysaccharide & 53 \\
\hline $\begin{array}{l}\text { Phellinus linteus (Current name: Tropicoporus linteus (Berk. \& } \\
\text { M.A. Curtis) L.W. Zhou \& Y.C. Dai), }\end{array}$ & Newcastle disease virus (NDV) & Crude extract & 54 \\
\hline Lentinus squarrosulus Mont., Pleurotus ostreatus (Jacq.) P. Kumm. & Human Cytomegalovirus (HCMV) & Methanol extract & 55 \\
\hline
\end{tabular}

\section{Conclusion}

Proper and balanced nutrition plays an important role in preventing diseases. In this context, adding mushrooms, which have important biological activities, to the diet list is important in the prevention of diseases as well as their nutritious properties. Today, due to the high antiviral effects of many fungal species, its use before, in the treatment and after the covid 19 can benefit human health. In this context, especially medicinal mushrooms can be used in the fight against COVID-19.

\section{Acknowledgments}

None.

\section{Conflicts of interest}

The author declares that they have no potential conflict of interests.

\section{References}

1. WHO. Coronavirus disease (COVID-2019) situation reports.

2. Del-Rio C, Malani PN. COVID-19 - new insights on a rapidly changing epidemic. Jama. 2020;323:1339-1340.

3. Yang P, Wang X. COVID-19: a new challenge for human beings. Cellular \& molecular immunology. 2020;17(5):555-557.

4. Liu C, Zhou Q, Li Y, et al. Research and Development on Therapeutic Agents and Vaccines for COVID-19 and Related Human Coronavirus Diseases. ACS Cent Sci. 2020;6:315-331.

5. Mishu MA, Samiha F, Zahan K, et al. Multi-organ Dysfunction Due to SARS-CoV-2 Infection: A Comparative Overview. American Journal of Internal Medicine. 2021;9(1):26-35.

6. Krupodorova T, Sevindik M. Antioxidant potential and some mineral contents of wild edible mushroom Ramaria stricta. AgroLife Sci J. 2020;9:186-191.

7. Sevindik M. Antioxidant and antimicrobial capacity of Lactifluus rugatus and its antiproliferative activity on A549 cells. Indian Journal of Traditional Knowledge. 2020;19(2):423-427.

8. Sevindik M. Poisonous Mushroom (Nonedible) as an Antioxidant Source. Plant Antioxidants and Health, 2020:1-25.

9. Sevindik M, Akgul H, Korkmaz AI, et al. Antioxidant Potantials of Helvella leucomelaena and Sarcosphaera coronaria. J Bacteriol Mycol Open Access. 2018;6(2):00173.

10. Özaltun B, Sevindik M. Evaluation of the effects on atherosclerosis and antioxidant and antimicrobial activities of Agaricus xanthodermus poisonous mushroom. The European Research Journal. 2020;6(6):539544.

11. Sevindik M, Özdemir B, Braidy N. et al. Potential Cardiogenic Effects of Poisonous Mushrooms. The Journal of Fungus. 2021;12(1):80-86.

12. Gürgen A, Sevindik M, Yıldız S, et al. Determination of antioxidant and oxidant potentials of Pleurotus citrinopileatus mushroom cultivated on various substrates. Kahramanmaraș Sütçü İmam Üniversitesi Tarım ve Doğa Dergisi. 2020;23(3):586-591.
13. Sevindik M. Wild edible mushroom Cantharellus cibarius as a natural antioxidant food. Turkish Journal of Agriculture-Food Science and Technology. 2019;7(9):1377-1381.

14. Bal C, Sevindik M, Akgul H, et al. Oxidative stress index and antioxidant capacity of Lepista nuda collected from Gaziantep/Turkey. Sigma. 2019;37(1):1-5.

15. Sevindik M, Rasul A, Hussain G, et al. Determination of Anti-Oxidative, Anti-Microbial Activity and Heavy Metal Contents of Leucoagaricus leucothites. Pakistan journal of pharmaceutical sciences. 2019;31(5 (Supplementary)):2163-2168.

16. Sevindik M, Akgul H, Bal C, et al. Oxidative stress and heavy metal levels of Pholiota limonella mushroom collected from different regions. Current Chemical Biology. 2018;12(2):169-172.

17. Sevindik M. The novel biological tests on various extracts of Cerioporus varius. Fresenius Environmental Bulletin. 2019;28(5):3713-3717.

18. Wasser SP. Medicinal mushrooms in human clinical studies. Part I. Anticancer, oncoimmunological, and immunomodulatory activities: a review. International journal of medicinal mushrooms. 2017;19(4):279317.

19. Sevindik M, Pehlivan M, Dogan M, et al. Phenolic content and antioxidant potential of Terfezia boudieri. Gazi University Journal of Science. 2018;31(3):707-711.

20. Blagodatski A, Yatsunskaya M, Mikhailova V, et al. Medicinal mushrooms as an attractive new source of natural compounds for future cancer therapy. Oncotarget. 2018;9(49):29259.

21. Akgul H, Sevindik M, Coban C, et al. New approaches in traditional and complementary alternative medicine practices: Auricularia auricula and Trametes versicolor. J Tradit Med Clin Natur. 2017;6(2):239.

22. Bal C, Akgul H, Sevindik M, et al. Determination of the anti-oxidative activities of six mushrooms. Fresenius Envir Bull. 2017;26(10):62466252 .

23. Ma G, Yang W, Zhao L, et al. A critical review on the health promoting effects of mushrooms nutraceuticals. Food Science and Human Wellness. 2018;7(2):125-133

24. Sevindik M. Antioxidant activity of ethanol extract of Daedaleopsis nitida medicinal mushroom from Turkey. Mycopath. 2018;16(2):47-49.

25. Mushtaq W, Baba H, Akata I, et al. Antioxidant potential and element contents of wild edible mushroom Suillus granulatus. Kahramanmaras Sütçü İmam Üniversitesi Tartm ve Doğa Dergisi. 2020;23(3):592-595.

26. Valverde ME, Hernández-Pérez T, Paredes-López O. Edible mushrooms: improving human health and promoting quality life. International journal of microbiology. 2015;2015:376-387.

27. Bach F, Helm CV, Bellettini MB, et al. Edible mushrooms: a potential source of essential amino acids, glucans and minerals. International Journal of Food Science \& Technology. 2017;52(11):2382-2392.

28. Khan AA, Gani A, Khanday FA, et al. Biological and pharmaceutical activities of mushroom $\beta$-glucan discussed as a potential functional food ingredient. Bioactive Carbohydrates and Dietary Fibre. 2018;16:1-13.

29. Thu ZM, Myo KK, Aung HT, et al. Bioactive phytochemical constituents of wild edible mushrooms from Southeast Asia. Molecules. 2020; 25(8):1972. 
30. Sriramulu M, Sumathi S. Photocatalytic, antioxidant, antibacterial and anti-inflammatory activity of silver nanoparticles synthesised using forest and edible mushroom. Advances in Natural Sciences: Nanoscience and Nanotechnology. 2017;8(4):045012.

31. Sevindik M, Akata I. Antioxidant, oxidant potentials and element content of edible wild mushroom Helvella leucopus. Indian Journal of Natural Products and Resources. 2020;10(4):266-271.

32. Mallard B, Leach DN, Wohlmuth H, et al. Synergistic immuno-modulatory activity in human macrophages of a medicinal mushroom formulation consisting of Reishi, Shiitake and Maitake. PloS one. 2019;14(11): e0224740.

33. Sevindik M. Investigation of antioxidant/oxidant status and antimicrobial activities of Lentinus tigrinus. Advances in pharmacological sciences. 2018;2018:1718025.

34. Glamočlija J, Ćirić A, Nikolić M, et al. Chemical characterization and biological activity of Chaga (Inonotus obliquus), a medicinal "mushroom". Journal of ethnopharmacology. 2015;162:323-332.

35. Elbatrawy EN, Ghonimy EA, Alassar MM, et al. Medicinal mushroom extracts possess differential antioxidant activity and cytotoxicity to cancer cells. International journal of medicinal mushrooms. 2015;17(5):471479.

36. Sevindik M, Akgül H, Akata I, et al. Macrolepiota procera (Scop.) Singer Mantarının Ağır Metal İçeriklerinin ve Oksidatif Stres Durumunun Belirlenmesi. Süleyman Demirel Üniversitesi Fen Bilimleri Enstitüsü Dergisi. 2016;20(3):504-508.

37. Sevindik M, Akgül H, Günal S, et al. Pleurotus ostreatus' un doğal ve kültür formlarının antimikrobiyal aktiviteleri ve mineral madde içeriklerinin belirlenmesi. Kastamonu Üniversitesi Orman Fakültesi Dergisi. 2016;16(1):153-156.

38. Sevindik M. Investigation of oxidant and antioxidant status of edible mushroom Clavariadelphus truncatus. Mantar Dergisi. 2018;9(2):165168 .

39. Liu X, Wang L, Zhang C, et al. Structure characterization and antitumor activity of a polysaccharide from the alkaline extract of king oyster mushroom. Carbohydrate polymers. 2015;118:101-106.

40. Shao HJ, Jeong JB, Kim KJ, et al. Anti-inflammatory activity of mushroom-derived hispidin through blocking of NF- $\mathrm{BB}$ activation. Journal of the Science of Food and Agriculture. 2015;95(12):2482-2486.

41. Akgül H, Nur AD, Sevindik M, et al. Tricholoma terreum ve Coprinus micaceus'un bazı biyolojik aktivitelerinin belirlenmesi. Artvin Çoruh Üniversitesi Orman Fakültesi Dergisi. 2016;17(2):158-162.

42. Sandargo B, Michehl M, Praditya D, et al. Antiviral meroterpenoid rhodatin and sesquiterpenoids rhodocoranes A-E from the wrinkled peach mushroom, Rhodotus palmatus. Organic letters. 2019;21(9):3286-3289.

43. Piraino F, Brandt CR. Isolation and partial characterization of an antiviral, RC-183, from the edible mushroom Rozites caperata. Antiviral research. 1999;43(2):67-78.
44. Doğan HH, Karagöz S, Duman R. In vitro evaluation of the antiviral activity of some mushrooms from Turkey. International journal of medicinal mushrooms. 2018;20(3):201-212.

45. Santoyo S, Ramírez-Anguiano AC, Aldars-García L, et al. Antiviral activities of Boletus edulis, Pleurotus ostreatus and Lentinus edodes extracts and polysaccharide fractions against Herpes simplex virus type 1. Journal of food and nutrition research. Journal of Food and Nutrition Research. 2012;51(4): 225-235.

46. Lee SM, Kim SM, Lee YH, et al. Macromolecules isolated from Phellinus pini fruiting body: chemical characterization and antiviral activity. Macromolecular Research. 2010;18(6):602-609.

47. Teplyakova TV, Psurtseva NV, Kosogova TA. Antiviral activity of polyporoid mushrooms (higher Basidiomycetes) from Altai Mountains (Russia). International Journal of Medicinal Mushrooms. 2012;14(1):3745 .

48. Ellan K, Thayan R, Raman J, et al. Anti-viral activity of culinary and medicinal mushroom extracts against dengue virus serotype 2 : an in-vitro study. BMC complementary and alternative medicine. 2019;19(1):260.

49. Adotey G, Quarcoo A, Holliday J, et al. Effect of immunomodulating and antiviral agent of medicinal mushrooms (immune assist 24/7 TM) on CD4+ T-lymphocyte counts of HIV-infected patients. International Journal of Medicinal Mushrooms. 2011;13(2):109-113.

50. Kidukuli AW, Mbwambo ZH, Malebo HM, et al. In vivo antiviral activity, protease inhibition and brine shrimp lethality of selected Tanzanian wild edible mushrooms. Journal of Applied Biosciences. 2010;31(1):18871894.

51. Ogbole O, Segun P, Akinleye T, et al. Antiprotozoal, antiviral and cytotoxic properties of the Nigerian Mushroom, Hypoxylon fuscum Pers. Fr.(Xylariaceae). ACTA Pharmaceutica Sciencia. 2018;56(4):43-56.

52. Krupodorova T, Rybalko S, Barshteyn V. Antiviral activity of Basidiomycete mycelia against influenza type A (serotype H1N1) and herpes simplex virus type 2 in cell culture. Virologica sinica. 2014;29(5):284-290.

53. Faccin LC, Benati F, Rincão VP, et al. Antiviral activity of aqueous and ethanol extracts and of an isolated polysaccharide from Agaricus brasiliensis against poliovirus type 1. Letters in applied microbiology. 2007;45(1):24-28.

54. Lee D, Kim SC, Kim D, et al. Screening of Phellinus linteus, a medicinal mushroom, for anti-viral activity. Journal of the Korean Society for Applied Biological Chemistry. 2011;54(3):475-478.

55. Roy D, Ansari S, Chatterjee A. In Vitro Search for Antiviral Activity against Human Cytomegalovirus from Medicinal Mushrooms Pleurotus sp. and Lentinus sp. J Antivir Antiretrovir. 2020;12(3):201. 